\title{
Optimal Control of Mathematical Models on The Dynamics Spread of Drug Abuse
}

\section{Kontrol Optimal Model Matematika Terhadap Dinamika Penyebaran Penyalahgunaan Narkoba}

\author{
Nita Anggriani ${ }^{*}$, Syamsuddin Toaha ${ }^{2 *}$ Kasbawati $^{3^{*}}$
}

\begin{abstract}
This article examines the optimal control of a mathematical model of the spread of drug abuse. This model consists of five population classes, namely susceptible to using drugs $(S)$, light-grade drugs (A), heavy-grade drugs ( $H)$, medicated drugs $(T)$, and Recovery from drugs $(R)$. The system is solved using the Pontryagin minimum principle and numerically by the forward-backward sweep method. Numerical simulations of the optimal problem show that with the implementation of anti-drug campaigns and strengthening of self-psychology through counseling, the spread of drug abuse can be eradicated more quickly. The implementation of campaigns and strengthening of self-psychology through large amounts of counseling needs to be done from the beginning then the proportion can be reduced until a certain time does not need to be given anymore. The use of control in the form of strengthening efforts to self-psychology through counseling means that it needs to be done in a longer time to prevent the spread of drug abuse.
\end{abstract}

Keywords: The Drug Abuse, Mathematical Model, Pontryagin Minimum Principles, Forward-Backward Sweep, Optimal Control.

\begin{abstract}
Abstrak
Artikel ini membahas tentang kontrol optimal model matematika dinamika penyebaran penyalahgunaan narkoba. Model ini terdiri dari lima kelas populasi, yaitu rentan menggunakan narkoba atau Susceptible (S), penyalahgunaan narkoba tingkat ringan atau Lighter Users (A), penyalahgunaan narkoba tingkat berat atau Heavy Users $(H)$, penyalahgunaan narkoba melakukan pengobatan atau Treatment $(T)$, dan penyalahgunaan narkoba sembuh dan mengalami pemulihan atau Recovery $(R)$. Sistem diselesaikan dengan menggunakan prinsip minimum Pontryagin dan secara numerik dengan metode forward-backward sweep. Simulasi numerik dari masalah optimal menunjukkan bahwa dengan adanya upaya penerapan kampanye anti narkoba dan penguatan

* Program Studi Magister Matematika, FMIPA-UNHAS

Email: ${ }^{1}$ anggrianita93@gmail.com, ${ }^{2}$ syamsuddint@yahoo.com, ${ }^{3}$ kasbawati@gmail.com
\end{abstract}

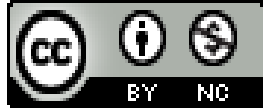

This work is licensed under a Creative Commons Attribution-NonCommercial 4.0 International License 
terhadap psikologi diri lewat konseling maka penyebaran penyalahgunaan narkoba dapat lebih cepat diberantas. Penerapan kampanye dan penguatan terhadap psikologi diri lewat konseling dalam jumlah besar perlu dilakukan sejak awal kemudian proporsinya dapat dikurangi sampai waktu tertentu tidak perlu lagi diberikan. Penggunaan kontrol berupa upaya penguatan terhadap psikologi diri lewat konseling perlu dilakukan dalam waktu yang lebih lama untuk mencegah terjadinya penyebaran penyalahgunaan narkoba.

Kata Kunci: Penyalahgunaan Narkoba, Model Matematika, Prinsip Minimum Pontryagin, Forward-Backward Sweep, Kontrol Optimal.

\section{Pendahuluan}

Narkotika adalah zat atau obat yang bersifat alamiah, sintetis, maupun semi sintetis yang menimbulkan efek penurunan kesadaran, halusinasi, serta daya rangsang. Manfaat dari penggunaan zat tersebut adalah sebagai obat penghilang rasa nyeri serta memberikan ketenangan. Obat-obatan tersebut jika pemakaiannya berlebihan akan menimbulkan kecanduan. Kandungan yang terdapat pada narkoba memberikan dampak buruk bagi kesehatan jika disalahgunakan [1]. Penyebaran dan penyalahgunaan narkoba di Indonesia adalah suatu pola perilaku seseorang yang menggunakan obat-obatan golongan narkotika, psikotropika, dan zat adiktif tidak sesuai fungsinya. Penyalahgunaan narkoba umumnya terjadi pada beberapa faktor terutama karena adanya rasa ingin tahu yang tinggi, kemudian menjadi kebiasaan. Selain itu, penyalahgunaan narkoba pada diri seseorang diakibatkan juga karena terdapat masalah dalam hidupnya dan berteman dengan pecandu narkoba [2]. Penyalahgunaan narkoba memiliki dampak negatif terhadap kesehatan, ekonomi, sosial bahkan menimbulkan kriminalitas. Bukan hanya berakibat kepada penggunanya saja, namun keluarga juga turut menjadi korban dari penyalahgunaan narkoba dalam skala besar sehingga dapat merugikan masyarakat, bangsa, dan negara. Masalah narkotika bukan hanya tentang penanganan, tapi juga pemberdayaan masyarakat, rehabilitasi, dan paling penting adalah pencegahaan.

Dinamika perubahan populasi merupakan salah satu kajian dalam pemodelan matematika yang mencoba mendeskripsikan fenomena dari sudut pandang matematika. Fenomena ditransformasikan ke dalam persamaan atau sistem persamaan, misalnya dalam populasi dinamis $[3,4,5]$ dan di bidang epidemiologi $[6,7,8]$. Dengan asumsi bahwa penyalahgunaan narkoba dapat menyebar dari satu sama lain, dinamika penyebaran penyalahgunaan narkoba juga dapat dipertimbangkan dalam pemodelan matematis. Beberapa penelitian sebelumnya telah memodelkan masalah yang berkaitan dengan dinamika penyebaran penyalahgunaan narkoba. Seperti contoh model matematika penyebaran penyalahgunaan narkoba yang dikembangkan pada tahun 2019 oleh Fikri L, dkk [9] yang membahas tentang efek penyalahgunaan narkoba pada masyarakat dengan model matematika SLHT (Susceptible, Lighter users, Heavy users, Treatment) dan peneliti Joan K, dkk [10] membahas tentang efek penyalahgunaan zat (obat) oleh pengemudi komersial dengan model matematika SDAR (Susceptible, Lighter users, Heavy users, Rehabilitasi) dimana jurnal yang ditulis mengenai penyalahgunaan narkoba yang telah mengikuti rehabilitasi kembali menjadi lighter users. Oleh sebab itu, pada penelitian ini berdasarkan fenomena yang disebutkan sebelumnya akan dilakukan modifikasi model dengan topik yang 
sama dari peneliti sebelumnya dalam sudut pandang matematika. Peneliti akan melakukan modifikasi dengan cara mengembangkan model perilaku narkoba menurut Fikri L, dkk [9] dengan menambahkan kelas populasi Recover $(R)$ dan beberapa kontrol optimal untuk meminimalisir terjadinya penyebaran penyalahgunaan narkoba. Peneliti akan mengkaji dinamika penyebaran penyalahgunaan narkoba dengan kontrol optimal.

\section{Model Dinamika Penyebaran Penyalahgunaan Narkoba}

Pengembangan model dalam penelitian ini merupakan pengembangan dari model dinamika penyebaran penyalahgunaan narkoba menurut Fikri L, dkk [9], kemudian diselesaikan dengan teori kontrol optimal. Hasil pengembangan model yang diperoleh adalah lima kelas populasi, yaitu Susceptible (S), Lighter Users (A), Heavy Users (H), Treatment (T), dan Recovery $(R)$. Pengembangan model dilakukan dengan menambahkan kelas Recovery $(R)$ dan beberapa faktor dalam upaya mengatasi masalah penyebaran penyalahgunaan narkoba.

Adapun asumsi yang dibentuk sebagai berikut:

1) Individu rentan yang beresiko menyalahgunakan narkoba dengan laju konstan sebesar $\Lambda$. Individu rentan melakukan interaksi terhadap penyalahgunaan narkoba tingkat ringan dan berat dari beberapa faktor sehingga berpindah ke kelas penyalahgunaan narkoba tingkat ringan dengan laju $\beta\left(1-u_{1}\right) S(\mathrm{~A}+\mathrm{H})$. Setiap kelas populasi mengalami kematian alami dan hanya kelas populasi penyalahgunaan narkoba tingkat berat saja yang mengalami kematian yang diakibatkan oleh penyalahgunaan narkoba.

2) Individu penyalahgunaan narkoba dalam tingkatan ringan bertambah karena adanya interaksi antara penyalahgunaan narkoba yang rentan dengan penyalahgunaan narkoba tingkat ringan dan berat dengan laju $\beta\left(1-u_{1}\right) S(\mathrm{~A}+\mathrm{H})$. Penyalahgunaan narkoba berpindah ke penyalahgunaan narkoba tingkat berat atau pecandu dengan laju konstan sebesar $\tau A$. Individu penyalahgunaan narkoba tingkatan ringan berkurang karena adanya keinginan berhenti dari narkoba, sehingga berpindah ke kelas treatment dengan laju $\omega A$.

3) Individu penyalahgunaan narkoba tingkat berat jika mendapatkan penanganan untuk berhenti dari narkoba maka akan berpindah ke kelas populasi treatment dengan laju $\rho H$.

4) Pada tahap treatment terdapat individu yang gagal menjalani pengobatan atau treatment sehingga kembali menjadi individu penyalahgunaan narkoba tingkatan berat dengan laju $\gamma_{1} T$, sedangkan pecandu yang berhasil menjalankan treatment berpindah ke kelas recovery dengan laju $\eta T$.

5) Individu penyalahgunaan narkoba yang telah dinyatakan sembuh dan sedang mengalami masa pemulihan atau recovery dapat kembali ke kelas populasi rentan menyalahgunakan narkoba yang disebabkan oleh beberapa faktor dengan laju $\gamma_{2} u_{2} R$ dan berpindah ke kelas penyalahgunaan narkoba tingkatan ringan dengan laju $\gamma_{2}\left(1-u_{2}\right) R$.

Diagram skematik dari lima kelas populasi dalam model dengan asumsi-asumsi di atas diberikan sebagai berikut: 


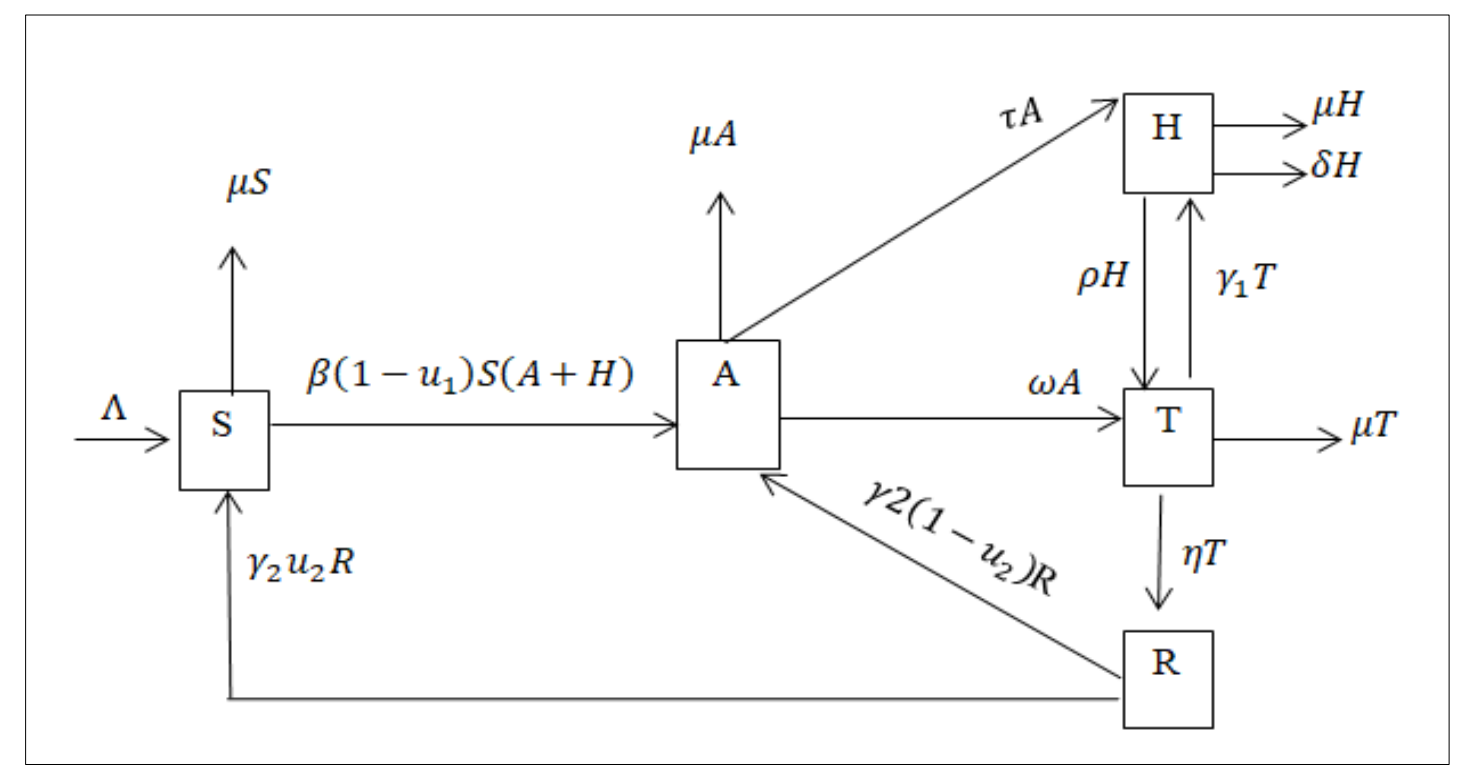

Gambar 2.1. Diagram Kompartemen Model Matematika Dinamika Penyebaran Penyalahgunaan Narkoba

Dari diagram kompartemen model tersebut, didapatkan sistem persamaan diferensial berikut:

$$
\left.\begin{array}{l}
\frac{d S(t)}{d t}=\Lambda-\beta\left(1-u_{1}\right) S(A+H)-\mu S+\gamma_{2} u_{2} R \\
\frac{d A(t)}{d t}=\beta\left(1-u_{1}\right) S(A+H)+\gamma_{2}\left(1-u_{2}\right) R-(\tau+\mu+\omega) A \\
\frac{d H(t)}{d t}=\tau A-(\mu+\delta+\rho) H+\gamma_{1} T \\
\frac{d T(t)}{d t}=\rho H+\omega A-\left(\mu+\gamma_{1}+\eta\right) T \\
\frac{d R(t)}{d t}=\eta T-\left(\gamma_{2}\right) R
\end{array}\right\}
$$

Dengan total populasi:

$N=S+A+H+T+R$.

Diasumsikan kondisi awal sistem memenuhi:

$S(0)=S_{0}, A(0)=A_{0}, H(0)=H_{0}, T(0)=T_{0}, R(0)=R_{0}$,

Dengan $S_{0}, A_{0}, H_{0}, T_{0}, R_{0} \geq 0$.

Keterangan variabel dan parameter yang digunakan dijelaskan pada tabel berikut.

Tabel 2.1. Daftar Variabel dan Parameter Model Dinamika Penyebaran Penyalahgunaan Narkoba

\begin{tabular}{clcc} 
Simbol & Keterangan & Syarat & Satuan \\
\hline $\boldsymbol{N}(\boldsymbol{t})$ & Total populasi pada suatu waktu $t$ & $N(t)>0$ & Orang \\
$\boldsymbol{S}(\boldsymbol{t})$ & $\begin{array}{l}\text { Total populasi yang rentan atau susceptible } \\
\text { mengunakan narkoba pada suatu waktu t }\end{array}$ & $S(t) \geq 0$ & Orang
\end{tabular}




\begin{tabular}{|c|c|c|c|}
\hline$A(t)$ & $\begin{array}{l}\text { Total populasi penyalahgunaan narkoba tingkat } \\
\text { ringan atau lighter users pada suatu waktu } t\end{array}$ & $A(t) \geq 0$ & Orang \\
\hline$H(t)$ & $\begin{array}{l}\text { Total populasi penyalahgunaan narkoba tingkat } \\
\text { berat atau heavy users pada suatu waktu } t\end{array}$ & $H(t) \geq 0$ & Orang \\
\hline$T(t)$ & $\begin{array}{l}\text { Total populasi penyalahgunaan narkoba melakukan } \\
\text { pengobatan atau treatment pada suatu waktu t }\end{array}$ & $T(t) \geq 0$ & Orang \\
\hline$R(t)$ & $\begin{array}{l}\text { Total populasi individu sembuh dan mengalami } \\
\text { masa pemulihan atau recovery pada suatu waktu t }\end{array}$ & $R(t) \geq 0$ & Orang \\
\hline$\Lambda$ & $\begin{array}{l}\text { Laju recruitment individu ke dalam kelas rentan } \\
\text { dengan usia } 6 \text { tahun ke atas }\end{array}$ & $\Lambda>0$ & Orang /tahun \\
\hline$\mu$ & Laju kematian alami individu & $\mu>0$ & $1 /$ tahun \\
\hline $\boldsymbol{\beta}$ & $\begin{array}{l}\text { Laju interaksi penyalahgunaan narkoba rentan } \\
\text { dengan penyalahgunaan narkoba tingkat ringan dan } \\
\text { tingkat berat }\end{array}$ & $\beta>0$ & $1 /$ tahun \\
\hline$\tau$ & $\begin{array}{l}\text { Laju perpindahan populasi penyalahgunaan } \\
\text { narkoba dari tingkat ringan ke tingkat berat }\end{array}$ & $\tau>0$ & $1 /$ tahun \\
\hline $\boldsymbol{\delta}$ & $\begin{array}{l}\text { Laju kematian akibat penyalahgunaan narkoba } \\
\text { tingkat berat }\end{array}$ & $\delta>0$ & $1 /$ tahun \\
\hline$\rho$ & $\begin{array}{l}\text { Laju perpindahan populasi penyalahgunaan dari } \\
\text { tingkat berat ke treatment }\end{array}$ & $\rho>0$ & $1 /$ tahun \\
\hline$\gamma_{1}$ & $\begin{array}{l}\text { Laju populasi penyalahgunaan narkoba dari } \\
\text { treatment ke tingkat berat }\end{array}$ & $\gamma_{1}>0$ & $1 /$ tahun \\
\hline $\boldsymbol{\eta}$ & $\begin{array}{l}\text { Laju populasi penyalahgunaan narkoba dari } \\
\text { treatment ke recovery }\end{array}$ & $\eta>0$ & $1 /$ tahun \\
\hline $\boldsymbol{\omega}$ & $\begin{array}{l}\text { Laju populasi penyalahgunaan narkoba tingkatan } \\
\text { ringan ke treatment }\end{array}$ & $\omega>0$ & $1 /$ tahun \\
\hline$\gamma_{2}$ & $\begin{array}{l}\text { Laju perpindahan pengguna narkoba dari recovery } \\
\text { ke pengguna tingkatan ringan }\end{array}$ & $\gamma_{2}>0$ & $1 /$ tahun \\
\hline$u_{1}$ & Proporsi efek penerapan kampanye anti narkoba & $0 \leq u_{1} \leq 1$ & - \\
\hline$u_{2}$ & $\begin{array}{l}\text { Proporsi efek penerapan penguatan terhadap } \\
\text { psikologi diri lewat konseling }\end{array}$ & $0 \leq u_{2} \leq 1$ & - \\
\hline
\end{tabular}

\section{Masalah Kontrol Optimal}

Pada penelitian ini permasalahan akan diselesaikan menggunakan kontrol optimal dengan tujuan untuk meminimumkan jumlah individu penyebaran penyalahgunaan narkoba dengan biaya 
penerapan kontrol $u_{1}$ dan $u_{2}$ yang minimum. Fungsi tujuan yang akan diminimumkan didefinisikan sebagai berikut:

$$
\min _{\left(u_{1}, u_{2}\right)} J=\min _{\left(u_{1}, u_{2}\right)} \int_{0}^{t_{f}}\left(C_{1} A(t)+C_{2} H(t)+\frac{1}{2} C_{3} u_{1}^{2}(t)+\frac{1}{2} C_{4} u_{2}^{2}(t)\right) d t
$$

dimana batas kontrol optimal berada pada $0 \leq u_{1}, u_{2} \leq 1,0 \leq t \leq t_{f}$ serta $t_{f}$ merupakan waktu akhir pengontrolan. Koefisien $C_{1}$ merupakan nilai bobot tujuan untuk mengurangi jumlah individu penyalahgunaan narkoba tingkat ringan, koefisien $C_{2}$ merupakan nilai bobot tujuan untuk mengurangi jumlah individu penyalahgunaan narkoba tingkat berat, koefisien $C_{3}$ merupakan nilai bobot dari fungsi kontrol $u_{1}$ yaitu upaya kampanye anti narkoba, dan koefisien $C_{4}$ merupakan nilai bobot tujuan dari fungsi kontrol $u_{2}$ yaitu upaya penyadaran penyalahgunaan narkoba dengan peguatan psikologi melalui konseling. Merepresentasikan persamaan (3.1) pencarian fungsi kontrol $\left(u_{1}{ }^{*}, u_{2}{ }^{*}\right) \in U$ sedemikian sehingga $J\left(u_{1}{ }^{*}, u_{2}{ }^{*}\right) \leq J\left(u_{1}, u_{2}\right)$ untuk setiap $\left(u_{1}, u_{2}\right) \in U$.

\section{Pembentukan Persamaan State, Costate, dan Syarat Kestasioneran}

Pada persamaan (3.1) diberikan masalah optimasi, kemudian akan ditentukan kontrol optimal $u^{*}$ yang memenuhi $J\left(u^{*}\right)=\min \{J(u): u \in U\}$. Berdasarkan prinsip minimum Pontryagin langkah pertama membentuk fungsi Hamilton terlebih dahulu untuk menyelesaikan fungsi tujuan pada persamaan (3.1) dengan kendala pada persamaan (2.1). Dari persamaan (3.1) diperoleh:

$$
f(t, x, u)=C_{1} A(t)+C_{2} H(t)+\frac{1}{2} C_{3} u_{1}^{2}(t)+\frac{1}{2} C_{4} u_{2}^{2}(t)
$$

Misalkan pengali Lagrange dari persamaan (2.1) yaitu $\lambda$ dan $\lambda^{T}$ adalah transpose dari $\lambda$ sehingga dapat dituliskan

$$
\lambda^{T}=\left(\begin{array}{lllll}
\lambda_{1} & \lambda_{2} & \lambda_{3} & \lambda_{4} & \lambda_{5}
\end{array}\right)
$$

maka fungsi Hamilton dapat diuraikan seperti berikut:

$$
\begin{aligned}
P(t, x, u, \lambda)=f & (t, x, u)+\lambda^{T}(t) g(t, x, u) \\
= & C_{1} A+C_{2} H+\frac{1}{2} C_{3} u_{1}^{2}+\frac{1}{2} C_{4} u_{2}^{2} \\
& +\lambda_{1}\left(\Lambda-\beta\left(1-u_{1}(t)\right) S(A+H)-\mu S+\gamma_{2} u_{2}(t) R\right) \\
& +\lambda_{2}\left(\beta\left(1-u_{1}(t)\right) S(A+H)+\gamma_{2}\left(1-u_{2}(t)\right) R-(\tau+\mu+\omega) A\right) \\
& +\lambda_{3}\left(\tau A-(\mu+\delta+\rho) H+\gamma_{1} T\right)+\lambda_{4}\left(\rho H+\omega A-\left(\mu+\gamma_{1}+\eta\right) T\right) \\
& +\lambda_{5}\left(\eta T-\left(\gamma_{2}\right) R\right) .
\end{aligned}
$$

Dari persamaan (4.1) akan ditentukan persamaan state,costate, dan syarat stasioner sebagai berikut:

- Persamaan state:

$$
\dot{x}=\frac{\partial P}{\partial \lambda}=\left(\frac{\partial P}{\partial \lambda_{1}}, \frac{\partial P}{\partial \lambda_{2}}, \frac{\partial P}{\partial \lambda_{3}}, \frac{\partial P}{\partial \lambda_{4}}, \frac{\partial P}{\partial \lambda_{5}}\right)^{T}
$$


diperoleh

$$
\begin{aligned}
& \dot{S}=\frac{\partial P}{\partial \lambda_{1}}=\Lambda-\beta\left(1-u_{1}(t)\right) S(A+H)-\mu S+\gamma_{2} u_{2}(t) R, \\
& \dot{A}=\frac{\partial P}{\partial \lambda_{2}}=\beta\left(1-u_{1}(t)\right) S(A+H)+\gamma_{3}\left(1-u_{2}(t)\right) R-(\tau+\mu+\omega) A \\
& \dot{H}=\frac{\partial P}{\partial \lambda_{3}}=\tau A-(\mu+\delta+\rho) H+\gamma_{1} T, \\
& \dot{T}=\frac{\partial P}{\partial \lambda_{4}}=\rho H+\omega A-\left(\mu+\gamma_{1}+\eta\right) T, \\
& \dot{R}=\frac{\partial P}{\partial \lambda_{5}}=\eta T-\left(\gamma_{2}\right) R .
\end{aligned}
$$

- Persamaan costate

diperoleh:

$$
\dot{\lambda}=-\frac{\partial P}{\partial x}=\left(-\frac{\partial P}{\partial S},-\frac{\partial P}{\partial A},-\frac{\partial P}{\partial H},-\frac{\partial P}{\partial T},-\frac{\partial P}{\partial R}\right)^{T}
$$

$$
\begin{aligned}
& \dot{\lambda_{1}}=-\frac{\partial P}{\partial S}=\left(\lambda_{1}-\lambda_{2}\right)\left(\beta\left(1-u_{1}(t)\right)(A+H)\right)+\mu \lambda_{1} \\
& \dot{\lambda_{2}}=-\frac{\partial P}{\partial A}=-C_{1}+\left(\lambda_{1}-\lambda_{2}\right)\left(\beta\left(1-u_{1}(t)\right) S\right)+\left(\lambda_{2}-\lambda_{3}\right) \tau+\left(\lambda_{2}-\lambda_{4}\right) \omega+\mu \lambda_{2} \\
& \dot{\lambda_{3}}=-\frac{\partial P}{\partial H}=-C_{2}+\left(\lambda_{1}-\lambda_{2}\right)\left(\beta\left(1-u_{1}(t)\right) S\right)+\left(\lambda_{3}-\lambda_{4}\right) \rho+\lambda_{3}(\delta+\mu) \\
& \dot{\lambda_{4}}=-\frac{\partial P}{\partial T}=\left(\lambda_{4}-\lambda_{3}\right) \gamma_{1}+\left(\lambda_{4}-\lambda_{5}\right) \eta+\lambda_{4} \mu \\
& \dot{\lambda_{5}}=-\frac{\partial P}{\partial R}=\left(\lambda_{2}-\lambda_{1}\right)\left(\gamma_{2} u_{2}(t)\right)+\left(\lambda_{5}-\lambda_{2}\right)\left(\gamma_{2}\right) .
\end{aligned}
$$

- Syarat stasioner

Bentuk $u_{1}$ dan $u_{2}$ yang optimal diperoleh dengan menggunakan syarat stasioner diberikan oleh:

dari syarat stasioner diperoleh:

$$
\dot{\lambda}=\frac{\partial P}{\partial u}=\left(\frac{\partial P}{\partial u_{1}}, \frac{\partial P}{\partial u_{2}}\right)^{T}=0
$$

$$
\begin{gathered}
u_{1}=\frac{\left(\lambda_{2}-\lambda_{1}\right)(\beta S(A+H))}{C_{3}}, \\
u_{2}=\frac{\left(\lambda_{2}-\lambda_{1}\right)\left(\gamma_{2} R\right)}{C_{4}},
\end{gathered}
$$

sehingga diperoleh kontrol optimal $u_{1}{ }^{*}$ dan $u_{2}{ }^{*}$ sebagai berikut:

$$
\begin{gathered}
u_{1}^{*}=\min \left\{\max \left\{0, \frac{\left(\lambda_{2}-\lambda_{1}\right)(\beta S(A+H))}{C_{3}}\right\}, 1\right\}, \\
u_{2}^{*}=\min \left\{\max \left\{0, \frac{\left(\lambda_{2}-\lambda_{1}\right)\left(\gamma_{2} R\right)}{C_{4}}\right\}, 1\right\} .
\end{gathered}
$$

\section{Simulasi Numerik}


Penggunaan narkoba tetap menjadi ancaman bagi kesehatan masyarakat bagi Negara maju dan berkembang. Peneliti Mushadzesa, dkk menggunakan strategi intervensi ketergantungan waktu dimana setelah 14 tahun memungkinkan efektif pengurangan penggunaan narkoba [9]. Pada bagian ini dilakukan simulasi numerik untuk mendapatkan solusi optimal sistem.dengan menggunakan nilai yang diperoleh dari $[5,7,9]$ dan beberapa asumsi untuk simulasi diberikan nilai awal dari masing-masing populasi adalah $S(0)=9000, A(0)=4000, H(0)=500, T(0)=2000$, dan $R(0)=1000$, nilai bobot yang digunakan $C_{1}=10, C_{2}=75, C_{3}=55, C_{4}=50$ dan nilai parameter yang digunakan $\Lambda=100, \tau=0.05, \omega=0.65, \eta=0.8, \beta=0,0009, \gamma_{1}=0.07, \rho=$ $0.5, \mu=0.5, \delta=0.2$, dan $\gamma_{2}=0.69$. Metode numerik yang digunakan adalah metode forwardbackward sweep. Interval waktu $\left[t_{0}, t_{f}\right]$ yaitu $t_{0}=0$ dan waktu akhir $t_{f}=20$ tahun, begitu pula dengan fungsi kontrol $u_{i}=\left(u_{i 1}, \ldots, u_{i n}\right)$ dengan $u_{i j} \approx u_{i}\left(b_{j}\right), i=1,2$ dan $j=1, \ldots, n$. Solusi $x(t)$ dan $\lambda(t)$ dicari dengan menggunakan metode forward-backward Runge-Kutta orde 4. Sedangkan nilai $u_{i}$ diperbaharui dari setiap iterasi menggunakan $u=\frac{\left(u_{\text {lama }}+u_{\text {baru }}\right)}{2}$, dengan $u_{\text {baru }}$ diperoleh dari syarat keoptimalan $\frac{\partial P}{\partial u}[11]$.

Pada pemaparan sebelumnya, telah dijelaskan bahwa terdapat dua macam kontrol dalam model penyebaran perilaku penyalahgunaan narkoba ini, yaitu kontrol $u_{1}(t)$ merupakan upaya penerapan kampanye anti narkoba dan kontrol $u_{2}(t)$ merupakan upaya penerapan penguatan psikologi diri lewat konseling. Adapun bentuk grafik yang optimal dari $u_{1}(t)$ dan $u_{2}(t)$ dapat dilihat pada gambar berikut.

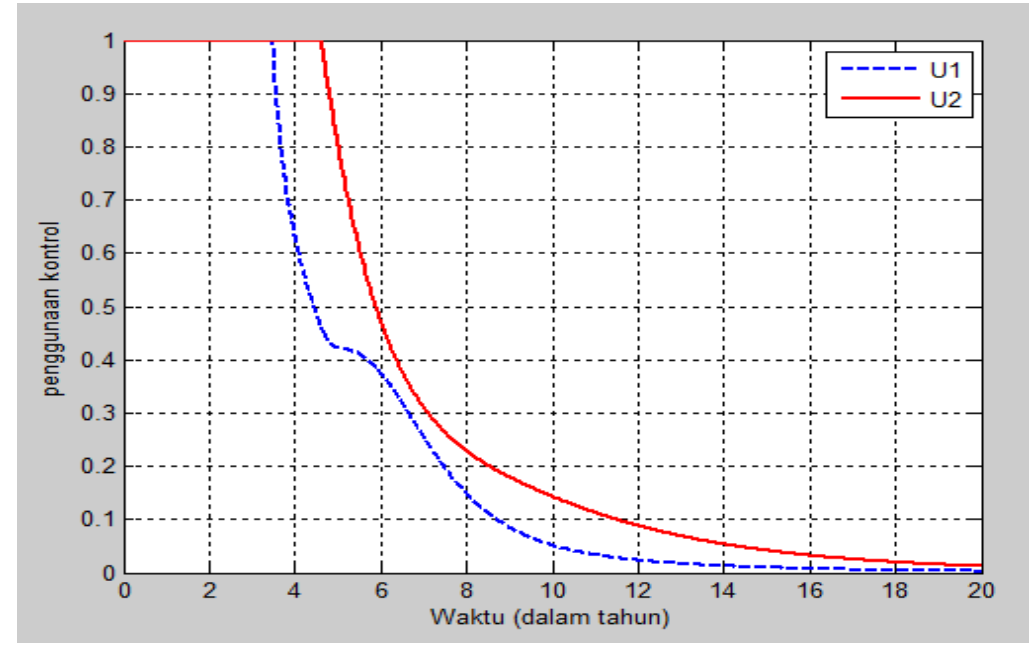

Grafik 5.1. Grafik Perbandingan Fungsi Kontrol Optimal $u_{1}{ }^{*}(t)$ dan $u_{2}{ }^{*}(t)$

Pada Gambar 5.1, terlihat bahwa pada awal waktu sampai waktu $t=3$ tahun, nilai $u_{1}{ }^{*}(t)$ dan $u_{2}{ }^{*}(t)$ memiliki nilai konstan yang sama yaitu bernilai 1 . Hal ini menunjukkan bahwa upaya penerapan kampanye anti narkoba dan penguatan terhadap psikologi diri lewat konseling perlu dilakukan dengan maksimal secara bersamaan diawal waktu sampai $t=3$ tahun. Dari gambar tersebut juga dapat dilihat adanya kondisi nilai $u_{1}{ }^{*}(t)$ dan $u_{2}{ }^{*}(t)$ terus mengalami penurunan 
seiring dengan berjalannnya waktu, dimana kondisi nilai $u_{1}{ }^{*}(t)$ mengalami penurunan lebih awal pada saat $t=3$ tahun, dibandingkan dengan nilai $u_{2}{ }^{*}(t)$ yang mengalami penurunan saat $t=5$ tahun. Penurunan nilai $u_{1}{ }^{*}(t)$ lebih awal dibandingkan dengan $u_{2}{ }^{*}(t)$ disebabkan bobot biaya untuk upaya penerapan kampanye anti narkoba $\left(u_{1}{ }^{*}(t)\right)$ lebih besar dibandingkan dengan penguatan terhadap psikologi diri lewat konseling $\left(u_{2}{ }^{*}(t)\right)$. Penurunan dari grafik $u_{1}{ }^{*}(t)$ dan $u_{2}{ }^{*}(t)$ juga menunjukkan bahwa saat kondisi individu yang menyalahgunakan narkoba sudah mulai berkurang, maka upaya penerapan kampanye anti narkoba dan penguatan terhadap psikologi diri lewat konseling harus pula dikurangi.

\section{Kesimpulan}

Model matematika dinamika penyebaran penyalahgunaan narkoba dikembangkan dengan lima kompartemen yaitu rentan menggunakan narkoba atau Susceptible $(S)$, penyalahgunaan narkoba tingkat ringan atau Lighter Users (A), tingkat berat atau Heavy Users $(H)$, penyalahgunaan narkoba melakukan pengobatan atau Treatment $(T)$, dan penyalahgunaan narkoba yang sembuh dan mengalami masa pemulihan atau Recovery $(R)$ dengan pemberian penerapan kontrol optimal berupa efek penerapan kampanye anti narkoba dan penguatan terhadap psikologi diri lewat konseling sehingga dapat meminimalkan terjadinya penyebaran penyalahgunaan narkoba. Diperoleh dua bentuk kontrol optimal yaitu:

$$
\begin{aligned}
& u_{1}^{*}=\min \left\{\max \left\{0, \frac{\left(\lambda_{2}-\lambda_{1}\right)(\beta S(A+H))}{C_{3}}\right\}, 1\right\} \\
& u_{2}^{*}=\min \left\{\max \left\{0, \frac{\left(\lambda_{2}-\lambda_{1}\right)\left(\gamma_{2} R\right)}{C_{4}}\right\}, 1\right\} .
\end{aligned}
$$

Berdasarkan hasil simulasi numerik, diperoleh bahwa penerapan kontrol optimal berupa efek penerapan kampanye anti narkoba berkurang lebih cepat jika dibandingkan dengan penerapan penguatan terhadap psikologi diri lewat konseling. Penerapan kontrol tersebut artinya masyarakat perlu diberikan edukasi lebih lama.

\section{Daftar Pustaka}

[1] Alodokter., 2018. www.alodokter.com/penyalahgunaan-napza. [10 Juli 2020]

[2] Badan Narkotika Nasional., 2019. https://bnn.go.id/penggunaan-narkotika-kalanganremaja-meningkat/. [ 10 Juli 2020]

[3] Beay L. K., Kasbawati \& Toaha S., 2017. Effects Of Human And Mosquito Migrations On The Dynamical Behavior Of The Spread Of Malaria. AIP Conference Proceedings Vol 1825, 020006 (2017). doi.org/10.1063/1.4978975.

[4] Hartati, H., Toaha, S. \& Kasbawati., 2019. Stability Analysis of SEISEIR-SEI Modelling on The Dynamics of Spread Dengue Fever with Vaccination and Insecticide J. Phys.: Conf. Ser. 1341 062033. doi:10.1088/1742-6596/1341/6/062033. 
[5] Kavuti, Joan K., Shaibu Osman \& Mary Wainaina., 2018. Mathematical Modelling of Substance Abuse by Commercial Drivers. Dapertment Of Mathematics and Actuarial Science, Catholic University of Eastern Africa.

[6] Lenhart, S. \& Workman, J. T., 2007. Optimal Control Applied to Biological Models. London: Taylor \& Francis Group.

[7] Lucas, Fikiri M. \& Dmitry Kuznetsov., 2019. Mathematical Modelling on the Effects of Drug Abuse to the Societies. Dapertment of Applied Mathematics The Nelson Mandela Africa Institute of Science and Technology Arusha, Tanzania.

[8] Muin, R. M., Toaha, S. \& Kasbawati., 2019. Effect of Vaccination and Treatment on The MSEICR Model Of The Transmission Of Hepatitis B Virus J. Phys.: Conf. Ser. 1341 062031. doi:10.1088/1742-6596/1341/6/062031.

[9] Mushadzesa, S. \& Tapedzesa, G. 2015. Modelling Illcit Drug Use Dynamics and Its Optimal Control Analysis. Computational and Mathematical Method in Medicine, Vol 2015

[10] Toaha S, Kusuma J, Khaeruddin \& Bahri M., 2014. Stability Analysis and Optimal Harvesting Policy of Prey-Predator Model with Stage Structure for Predator. Applied Mathematical Sciences, 8 (159), 7923-7934.

[11] Toaha, S. \& Rustam., 2017. Optimal Harvesting Policy of Predator-Prey Model with Free Fishing and Reserve Zones. AIP Conference Proceedings Vol. 182502002.

[12] Toaha, S. \& Azis, M.I., 2018. Stability and Optimal Harvesting of Modified Leslie-Gower Predator-Prey Model IOP. Conf. Series: Journal of Physics Vol. 979, No.1, 12069. 